\title{
The Consequences of International Migration for the Status of Women: A Turkish Study ${ }^{1}$
}

\author{
Lincoln H. Day* and Ahmet Içduygu**
}

\begin{abstract}
As part of a larger inquiry into the consequences of international migration for those who remain in the country of origin, 234 adults in four Turkish provinces were interviewed concerning matters (mostly opinions) pertaining to the status of women. Three migrant-status categories were defined; (a) Returned migrants, (b) Non-migrant close kin or friends of migrants, and, as a control group, (c) All others. Controlling for age, sex, urban-rural residence, and schooling, group (a) was the most likely to express"non-traditional" views, and group (c) the least. Group (b) was in between.

Of the two possible explanations for such a pattern - recruitment and socialization - we found recruitment highly significant. The evidence for socialization, however, was decidedly mixed. Some of the considerable diversity of viewpoints pertaining to the status of women found in this inquiry are doubtless causally associated with the experience of migration, whether direct or indirect. But there is also evidence here of a society in the process of rapid change; and it is these more general social changes, not migration as such, that would appear to be more likely to affect the status of women.
\end{abstract}

There is little support for the contention that the type of international migration that has involved so many Turks these past three decades migration that has for the most part been temporary and economically motivated and has consisted of movement from relatively poor agricultural or but slightly industrialized areas to rich, highly industrialized ones

* Washington D.C., USA.

**Bilkent University, Ankara, Turkey. 
characterized by marked differences in language, religion, and overall culture - is going to result in moving the status of women from a more to a less "traditional" plane.

\section{INTRODUCTION}

The consequences of migration, whether within or between countries, are experienced at three general levels: for the migrants themselves; the society they enter; and the society they leave. Social researchers have tended to focus on the first. Although there are exceptions (e.g., Abadan-Unat et al., 1976; Yenisey, 1976; Engelbrektsson, 1978; Gordon, 1978; Bennett, 1979; McArthur, 1979; Rhoades, 1979; Grasmuck, 1982; Khattab and El Daeif, 1982; Khafagi, 1983; Alpay and Sariaslan, 1984; Azmaz, 1984; Morauta, 1984; Gunatilleke (Ed.), 1992; Bocker, 1995), most researchers have either ignored the consequences for societies of origin, or considered them from only a limited perspective. They have commonly addressed internal movements (usually rural to urban) to the exclusion of international and, more important, have tended to restrict the scope of their inquiries to narrowly economic concerns, and generally at such a high level of generality (at the national level, for the most part, and in terms of such measures as balance of payments, average employment levels and wage rates), as to not only eclipse individual behaviour and differences but also to consider issues of mutual causation and context, if at all, only by inference.

The movement of human beings across national boundaries, in both scope and volume, has been one of the most striking social phenomena of the past one hundred and fifty years. Until recently, this movement was limited largely to Europeans to the New World. While migration statistics suffer from poor international comparability as to definition, coverage and completeness, it is generally accepted that, in the century or so before the middle of the present century, more than 60 million persons were admitted by the traditional immigrant-receiving countries, and that the great majority of these persons were Europeans. Although the migration of Europeans has continued to the present day, the overall pattern of migration is now quite different. Recent decades have seen enormous changes in magnitude, direction and length of stay abroad. The movement of Europeans is now only a fraction of the total non-tourist flow of persons between countries; and movement out of Europe is more than counterbalanced by movement into Europe. Persons from developing countries have moved to centre stage and now constitute not only the majority of permanent immigrants to traditional receiving countries, but also the major elements in flows of other types of migration. Most of those now living outside their homelands - an estimated 20 million contract workers, millions of refugees, hundreds of thousands of transient professional workers, and un- 
known numbers (but clearly millions) of illegal workers (Appleyard, 1989: 19) - are non-European.

The recent migration of non-Europeans has doubtless influenced economic growth and socio-economic change in many developing countries, most especially, but not exclusively, by way of remittances from hard currency areas and the acquisition by contract workers of new experiences and skills (Appleyard, 1989: 19). Although study of the consequences of movement within countries can yield insights concerning the consequences of movement between countries, the two types of movement are hardly the same. Differences between migrant and host societies - in language, religion and a variety of other cultural attributes - are predictably far greater, on the whole, with international than with internal movement, as are limitations on the frequency and types of contacts migrants will have with both the host society and the society of origin (Du Toit and Safa, 1975; Gulick, 1976; Hugo, 1978). Such differences in structure can hardly help but produce differences in outcomes as well.

\section{MIGRATION AND THE STATUS OF WOMEN}

The overall concern of the larger research effort underlying the findings presented in this article is the role played by international migration (particularly migration between markedly different cultures and levels of living) in fostering or retarding social change in societies of origin: the elements and sectors of the society likely to be more affected and those likely to be less affected; how these effects take place, and through what means. Our specific concern is with the possible consequences of international emigration for the status of women - a matter of both practical and theoretical significance.

Women have been significant participants in contemporary large-scale migrations of non-Europeans, both as migrants themselves, and (especially in the case of international contract workers) as non-migrating members of migrants' families. Although the former has increased among female Turkish migrants, the latter has been the far larger category, certainly up to the time of this inquiry (SOPEMI-OECD, 1988: 35, cited in Kadioglu, 1994: 533).

By "status of women" we mean the mutually influencing combination of (a) how women in a given society see themselves and (b) how they are seen by others in that society. What, if any, effect has emigration had on the status of women in the countries they left? The experience of emigration, either direct as an emigrant oneself or indirect as the close kin or friend of an emigrant, would appear to be of particular significance for change in the status of women. Migration offers at least the possibility of experiencing such forces for change as extensive contact with another culture, the separation of spouses and of 
parents and children, the absence of reinforcements for one's prior heritage as well as of constraints on alternative behaviours, marked increases in wealth and income, more material possessions, the experience of coping with the unfamiliar and of doing so in the absence of prior social supports, and the formation of conflicting or competing social networks and emotional ties. The experience of emigration holds out the possibility of one simultaneously coming into contact with new ways and of losing supports for old ways, of undertaking new roles and abandoning old roles and of acquiring new skills, new interests, new aspirations.

\section{LOCALE OF THE STUDY}

Turkey as a particularly appropriate country for such inquiry, first because of its high rate of emigration, and second because its experience of emigration is of only recent origin. Since the signing of the bilateral Turkish-West German agreement (31 October 1961) (which initially permitted Turkish men to enter West Germany on temporary one year work contracts and was later expanded to include women and families), hundreds of thousands of Turkish men and women have emigrated, mainly to Western Europe but also to Australia and, more recently (in larger numbers than to Australia) to the Arab countries of both North Africa and the Persian Gulf. By the mid-1990s, when the population of Turkey was 57 million, there were more than 2.5 million Turkish workers and their dependants in Europe, about 170,000 Turkish workers (without dependants) in Arab countries, and about 40,000 settlers in Australia (Gökdere, 1994: 37). On the basis that about 5 to 6 per cent of Turkey's population were therefore abroad, and that an estimated 30 to 40 per cent of them return permanently to Turkey, it would appear not only that a sizeable minority of the present Turkish population has had a direct experience of emigration, but also that an even larger proportion (through the emigration of a close relative or friend) has had an indirect experience.

Turkish migrants appear to have maintained a high level of contact with family and friends in the homeland through letters, telephone calls and remittances, and many have visited Turkey on holiday, to attend weddings or in response to the sickness or death of a relative. One could therefore reasonably expect that this combination of large-scale emigration with maintenance of a high level of contact with the country of origin would be an important stimulus for change in the economic and social life of Turkey. This recency of migration offered the possibility, so far as social research is concerned, of identifying for comparative purposes a control group of persons presumably relatively unaffected (at least in any direct sense) by the experience of migration, whether of themselves or of close kin or friends. In designing the inquiry, it was therefore possible to envisage three distinct categories of persons: (a) returned migrants, (b) non- 
migrants who were close relatives or friends of migrants (whether or not these migrants had returned), and, as a control group, (c) non-migrants who were not close relatives or friends of migrants.

\section{METHOD OF INQUIRY}

The study is based on results of lengthy, detailed interviews with adult men and women in four Turkish provinces, ranging from more developed and urban (Ankara, Izmir) to less developed and rural (Konya, Yozgat). Ankara (city population 3 million) and Izmir (city population 2 million), two of the main metropolitan areas in Turkey, have been major sources of migrants to many receiving countries and regions (Germany, Australia, North Africa and the Gulf States). They are also the main areas to which migrants have returned. Konya (city population 550,000), in the country's richest grain-growing area, has been a major source of migrants for several receiving countries, especially in Scandinavia. Yozgat (city population 45,000), an underdeveloped region, has been a source of migrants to a variety of countries.

These provinces were chosen not only because they are representative of the major outward and return flows, but also because the project's Director of Fieldwork (Içduygu) believed that his five years experience in the region would make it easier to obtain the cooperation of migrant/return migrant communities and also provide some logistic advantages. Moreover, the results of research already conducted on migrant and non-migrant communities in three of the provinces could be used for comparative purposes. ${ }^{2}$

All respondents $(\mathrm{N}=234)$ were aged 18 years and over and lived in 115 households. Eighty-three (47 men and 36 women) were returned migrants; 54 (6 men and 48 women) were close relatives of migrants, whether or not returned; 19 ( 3 men and 16 women) were close friends of migrants, whether or not returned; 34 (17 men and 17 women) were both close relatives and close friends of migrants, whether or not returned; and 44 ( 24 men and 20 women) were "controls", i.e., neither migrants themselves nor close relatives or friends of migrants. Respondents were drawn in approximately equal numbers from each of the four provinces and, within each province, in approximately equal numbers from both urban and rural districts. The first step in the selection process was to compile from files assembled by the Fieldwork Director during earlier research undertaken in Australia (Içduygu, 1991), a list of the names and Turkish addresses both of migrants who had returned from Australia and of close relatives and friends in Turkey of migrants who had remained in Australia. Potential respondents in the context of migration other than Australia (e.g., Europe and the Arab countries) were drawn from the same neighbourhood areas as those with an Australian connection, using the "web" or "chain" 
technique (Kadioglu, 1994: 540) whereby respondents are asked about other eligible families in the vicinity. Interviewers were instructed to seek out respondents with particular migration experience or in particular age, sex, length of stay abroad or country of destination categories, an approach similar to the one applied by A.T. Day (1985). The resulting distribution by migrant category is as follows:

\begin{tabular}{cccrl} 
Men & Women & Total & Per cent of Total \\
47 & 36 & 83 & 35 & $\begin{array}{l}\text { Returned migrants } \\
26\end{array}$ \\
\hline 1 & 107 & 46 & $\begin{array}{l}\text { Non-migrants who are close kin } \\
\text { or close friends of migrants }\end{array}$ \\
24 & 20 & 44 & 19 & $\begin{array}{l}\text { Controls (non-migrants who are neither } \\
\text { close kin nor close friends of migrants) }\end{array}$ \\
\hline 97 & 137 & 234 & 100 &
\end{tabular}

The seven interviewers, including the Director of Fieldwork, were Turkish and originally from districts in which the interviews were conducted ${ }^{3}$ between October 1992 and March 1993. Following six training sessions, each interviewer's first five interviews (which took place in both urban and rural parts of Yozgat province) were conducted under the close supervision of the Director of Fieldwork. Interviews were arranged either by telephone or face-to-face contact. The interviewers generally worked in teams consisting of one man and one woman. Upon arrival at place of interview, a household record sheet was completed with information obtained from either the household head or his/her spouse. Each member of the household aged 18 years or over was then interviewed in private for about one to one and a half hours. Men were interviewed by men and women by women. Respondents were assured of the confidentiality of their answers; tape recorders were not used. The high level of cooperation by respondents was due, in part, to the dedication of the young, closely supervised interviewers, and in part to the fact that Turks, on the whole, have had little experience of this kind of research and are therefore not yet "researched-out".

In addition to obtaining a number of background and socio-economic items usual in inquiries of this type, the interviews sought data on such matters as the extent and variety of contact maintained between migrants and those remaining in Turkey, perceptions of the future, levels of aspiration for oneself and one's family, general attitudes of optimism or pessimism, religiosity, the experiences of women, material possessions, views about migration, views along a general "modernist"-"traditionalist" continuum, and views on women's rights and on their status and role. It is the findings on these last items that are reported in this article. 
It was not our intention to describe Turkish society or to identify either the relative magnitudes of the various sectors of the Turkish population or the types of belief or behaviour among them. Our objective was to ascertain the association (or lack of it) between migrant status and various items of behaviour, belief and attitude, irrespective of the proportionate distribution of these phenomena within the Turkish population as a whole. We acknowledge the many problems associated with this type of research, for example, definition, appropriateness of questions, coding, respondents' understanding of questions or their mood at time of interview. However in any study of this type, the number of Ns is the main limitation on the number of factors that can be simultaneously controlled for. The large amount of information obtained makes this a matter of particular concern. Almost any cross-tabulation of data produces a plethora of empty cells. We have addressed this problem in two ways. First we have combined values in the major control categories so as to attain cells with more workable Ns, reducing Age to four categories, Migrant Status to three, Level of Schooling to five, and Residence to two. Second, we have limited our analysis to searching only for general patterns of relationship, as against employing one or another statistical test of significance. Slight statistical differences, unless part of such a pattern, were disregarded. These decisions were, we argue, justified not only by the generally small Ns in the cells created by cross-tabulations, but also by the fact that these data were not derived from a random sample. ${ }^{4}$

\section{FINDINGS}

Migrant status. At the most general level, what stands out about the association between migrant status and opinions relevant to the status of women is its consistency. Returned migrants tend to be concentrated at the more "progressive", less "traditional" end of the continuum, and the controls at the opposite end. In between (although generally closer to the migrants than to the controls) are non-migrants who are close kin or close friends of migrants. With respect to aspects of behaviour, for example, Tables 1, 2 and 3 (pages 361-363) indicate that only answers to question 9 (choosing one's husband) and 11 (daughter's schooling) fail to adhere to the pattern, and then only very slightly so.

Sex. There is less consistency when these opinions are cross-tabulated individually with sex, age, urban-rural residence or schooling. There was essentially no difference between men and women in the proportions who considered it a good idea for women to cover their hair, or acceptable for an unmarried man to have girl friends, or unacceptable for an unmarried woman to live alone; and although women were more supportive than men of tertiary schooling for women in general (and for their own sons and daughters specifically), the difference was only slight and the majorities of both sexes were in favour. 
The main differences between men and women relate to access to birth control (particularly on the part of married women), choice of husband, whether an employed woman should have control over her earnings, and the permissibility of an unmarried woman having boyfriends. On each of these issues, men were more likely to take a "traditional" view. While the majority of both sexes supported access to contraception for married women, opposition to the idea was more common among men, and men were more than half as likely as women to support the use of contraception by a married woman without the qualification that her husband should know about it. Men were also less likely to support married women's access to abortion.

Concerning unmarried women, the views were more restrictive. While a majority of both sexes opposed access to contraception for unmarried women, the size of the majority was greater among men than among women. The proportion in favour of allowing unmarried women unqualified access to abortion was also lower among men; but in cases of rape or threat to health, a majority of both sexes supported such access for unmarried women - and did so in equal measure.

Not surprisingly, perhaps, a higher proportion of women than men favoured allowing unmarried woman to have boyfriends (although a majority of both sexes opposed the idea), women to choose their husbands (though, even among women, the proportion favouring this in the face of a father's opposition, was only 51 per cent), women to have a job (irrespective of marital status), and an employed woman (again, irrespective of her marital status) to decide how to spend all or at least some of the money she earns.

Residence. There was essentially no difference between urban- and ruraldwellers concerning the acceptability of an unmarried man having girl friends, a married woman having access to abortion, or a woman having a job (irrespective of her marital status). The main differences between urban and rural dwellers related to whether it is a good idea for women to cover their hair, the acceptability of an unmarried woman living alone, the desirability of tertiary schooling for one's son and daughter and for women in general, and - as with the differences between men and women - the acceptability of an unmarried woman having boyfriends, access to birth control, choice of husband, work and the control of her earnings. In each of these, the proportion expressing the more "traditional" view was higher among rural than among urban dwellers. That is, there was greater support among rural-dwellers for women covering their hair and less support for an unmarried woman having boyfriends or living alone or having access to contraception or being allowed to choose her husband. There was also less support among rural dwellers for tertiary schooling, whether for women in general or for their own sons or daughters, and less support for an employed woman having control over the use of her earnings. This greater 
support for "traditionalism" would appear to be rounded out by the view on access of unmarried women to abortion: only 17 per cent of rural dwellers supported unqualified access as against 32 per cent of urban dwellers. However, when rape or health threat or rape alone was involved, the proportion in favour among those not already favouring unqualified access was 95 per cent among rural dwellers and 75 per cent among urban dwellers.

Age. Among the different age groupings, support for a more "traditional" view was expressed most often by those aged 55 years and older. They were least likely to approve of unmarried men having girlfriends, married women using contraception without their husbands' knowledge, unmarried women having access to contraception or, without qualifications, to abortion. Those in this category were also least likely to approve of unmarried women living alone, women choosing their own husbands, allowing an employed woman (whether married or unmarried) to decide how to spend her earnings, and tertiary schooling for their sons. They were also among those least likely to approve of unmarried women having boyfriends and tertiary schooling for either their own daughters or for women generally.

There were, however, some exceptions to this "traditional" pattern. These older respondents were the least likely to think women covering their hair was a good idea, and the most likely to say it did not matter. They were also on a par (95 per cent so reporting) with all the other age groupings in their support for allowing married women to have access to abortion, and they were also on a par (73 per cent so reporting) with all but the youngest age grouping in thinking it all right for a woman to have a paid job.

The least "traditional" views among the different age groupings were, by and large, expressed most often by those under age 35 , and usually by percentages substantially different from those in the other age groupings. They were by far the most supportive of unmarried men having girlfriends and unmarried women having boyfriends, married women using contraception even without the knowledge of their husbands, unmarried women having access to contraception, having unqualified access to abortion, and being allowed to live alone, and of women being allowed to choose their husbands even in the face of their fathers' objections. The younger respondents were also the most likely to approve of allowing women, regardless of marital status, to have paid jobs and to decide how the whole of their earnings are to be spent. The pattern among the 35-47 and 48-54 years age groupings generally fell between those of the youngest and oldest, although much closer to the latter.

Schooling. The least "traditional" pattern of views was found among those reporting the most schooling, and the most "traditional" among those reporting the least schooling. Concerning support for women covering their hair, for 
unmarried men having girlfriends and unmarried women having boyfriends, for allowing both married and unmarried women to use contraception, for allowing unmarried women to obtain an abortion, live alone, and choose their husbands, for tertiary schooling for women generally and for one's own son or daughter, and for allowing women to work for pay and to decide how to spend their earnings: those with some tertiary schooling expressed the greatest support and those with no schooling almost invariably the least. The one exception related to allowing married women to obtain abortions; here opposition was so slight (at least if the qualification of health threat is included) that there was little difference among the different schooling categories.

Despite the consistent relationship between the extremes, however, there was no particular consistency among the schooling levels in between. Those with primary schooling tended to express "traditional" views less often than one would anticipate if there were a steady progression in views from those with the least to those with the most schooling, and those with secondary-first level schooling tended to express such views more often than one would anticipate.

This generally consistent pattern by migrant status continues when controls are introduced for sex, age, urban-rural residence and schooling, despite the necessarily small numbers in the cells. Or, put perhaps more precisely, after the introduction of controls for sex, age, urban-rural residence, and schooling, what consistency there is tends to arise from association with migrant status, despite the small Ns produced by these controls. Some examples of this consistency follow. The first set (Table 4, pages 364-365) entails simultaneous controls for sex and age; the second (Table 5, pages 366-367) simultaneous controls for sex and schooling. The Ns for each set of examples pertain to all the examples in that set, and are introduced at the beginning of the respective sections. The questions have the same identifying numbers as when introduced earlier. We draw the following conclusions regarding this association (retaining the same identifying numbers for the questions as when first introduced).

Table 4 (controlling for sex and age) shows that although women tended to be less opposed than men to unmarried women having boyfriends (question 3), opposition among both women and men was consistently related to migrant status; generally lowest among returned migrants and highest among the controls. Women in all age groupings were considerably more likely than men to express unqualified approval of use of contraception by married women (question 5) and while approval was negatively associated with age among men, there was essentially no difference by age among women (except for the markedly lower proportion giving unqualified approval among migrant women aged 55 years and over). Among both men and women, however, the association with migrant status was consistent: approval being highest among returned migrants and lowest among the controls. Women were also generally more 
supportive than men concerning the use of contraception by unmarried women (question 6). But among both men and women, this support was quite consistently related to migrant status: highest among returned migrants and lowest among the controls. Women were also generally more supportive than men concerning access to abortion for unmarried women (question 8) (the exception being migrants aged 35-47 years), and there is a negative association between age and support. But, again, within all groupings there is a consistent association between support and migrant status: migrants being the most supportive and controls the least supportive.

Women were more in favour than men of allowing a woman to choose her own husband (question 9), especially in the higher age groupings, and migrant status was quite consistently associated with support for this idea. Women were also more supportive than men, and there was no particular association with age concerning whether an employed unmarried woman should be allowed to decide how to spend her earnings (question 14). Support was consistently associated with migrant status. However, women were somewhat less supportive of allowing an employed married women to decide how to spend her earnings than they were of allowing it to unmarried women (question 15). They were nonetheless still more supportive than men. As with unmarried women, there was a consistent association with migrant status: migrants being the most supportive and controls the least supportive.

Table 5 (controlling for sex and schooling) shows that women were more supportive than men of use by unmarried women of contraception (question 6) and there was a generally positive association with schooling among both sexes. The association with migrant status was generally consistent: the greatest support being among returned migrants and the least among the controls. There was a positive association between support and schooling regarding access to abortion for married women (question 7) and a pattern of general consistency (except at the lowest schooling level) between support and migrant status; the greatest support being among returned migrants, the least among the controls. Women were more likely than men to support the idea of allowing a women to choose her own husband, support which was positively associated with schooling among both sexes. There was a close association between support and migrant status among women; support being highest among migrants, lowest among the controls. But there was no particular comparable association among men. Opposition to a woman having a job for pay (question 13) generally decreased with increased schooling. Except among women with primary schooling, opposition was lowest among migrants and highest among the controls. Finally, on the question (14) of allowing an employed unmarried woman to decide how to spend her earnings, the association between schooling and opposition was generally negative. Opposition was also consistent with migrant status; lowest among migrants, highest among the controls. 


\section{DISCUSSION}

On the continuum of views relevant to women's status, returned migrants are furthest toward the more "progressive", less "traditional" end, and the controls furthest toward its opposite. In between, although generally closer to the migrants than to the controls, are the non-migrant close kin and close friends of migrants. This general pattern, although observed most clearly in the absence of controls for such presumably closely related characteristics as age, sex, schooling, and residence, also holds up when these controls are introduced. The existence of such a pattern says nothing about its origins. The possible causal explanations for such patterns can be assigned to one or other of two categories: recruitment and socialization.

Persons who choose to migrate are in some manner different from the rest of the society around them. In the circumstances of the particular migration under study, those who migrated could have been more ambitious, more willing to take risks, more materialistic, more idealistic, more discontented, more "progressive" or "modern". Whether the experience of migration subsequently reinforced or modified them, such traits could certainly have been a stimulus to migrate.

Similarly, the relative closeness of the response patterns of migrants and their non-migrating close kin and friends could be at least partly anticipated on the grounds that the two groups would probably have a number of such traits in common. That close kin and friends did not themselves migrate could be attributed either to their being more subject than the migrants to various countervailing pressures working against such action, or to their not possessing these traits to a degree sufficient to push them across the migration threshold. Either way, one could expect that migrants would harbour ideas at some variance with those held by the rest of the society; and that the non-migrating members of their close kin and friendship networks would do so as well, if not necessarily to the same extent.

But migration is more than a recruiting agent; it can also be a socializing agent, not only for the migrant but also for the non-migrating members of his or her network (as well as, less directly, for the rest of the society by way of the changes it can occasion in lifestyles, expectations, even institutional structures). At the least, the migrant is bound to have some experience of a different culture and lifestyle; his non-migrating wife, in consequence of his migration, might well experience new roles, or an improved economic position, or a greater sense of independence with the variety of changes in values and levels of aspiration that this could lead to. Whatever the stimuli in any particular instance, this process of socialization can take a great variety of forms. 
Assessing the relative importance of recruitment versus socialization in the determination of the patterns observed in our study is not an easy task. Data such as those to hand can, at best, only offer hints. Under ideal conditions, these would have been supplemented by others derived from a more in-depth interviewing of a selection of respondents located in categories of particular theoretical interest (A.T. Day, 1985 and 1991). Such a supplementary inquiry, unfortunately, was not possible in the present study. But it was possible to separate those in the close-kin-or-friends-of-migrants category into two categories according to whether they reported experiencing certain changes in living conditions and lifestyle as a result of the migration of a close relative or friend, and then compare these two groups' respective patterns of responses on the items presumed to be indicative of women's status.

\section{MIGRATION AND THE STATUS OF WOMEN}

How might the experience of migration, either direct (as a migrant) or indirect (as kin or close friend of a migrant), be expected to affect the status of women? The many, often mutually reinforcing, possibilities can be subsumed under the headings of three direct consequences of international migration: (a) separation of kin and friends, (b) enhanced economic well-being of migrants and their families, and (c) contacts with other persons and lifestyles.

The separation of spouses, or of children and their parents, could impose new (or enhance already existing) responsibilities, for example, those associated with shopping, caring for parents or children, management of a farm or business or the management of money; responsibilities which could lead women to acquire new skills, new aspirations or greater self-confidence; or which, in the case of migrant men, who might have had to assume responsibility for household maintenance or cooking while abroad, lead to development of a more sympathetic attitude toward women's work and capabilities. Such separation could also produce the same kinds of results through fostering the assumption of new roles (e.g., those associated with entering the labour market or obtaining employment outside the home or family setting), or the acquisition of new skills (such as learning to read, learning another language, learning to keep accounts or taking up midwifery), likely to enhance one's self-confidence (or diminish it, in the case of failure) through doing things not done before, such as making decisions about personal or household consumption, managing a business or farm, making decisions about or actually disciplining children, taking public transport to a nearby city on one's own, driving a car or tractor or dealing on one's own with officials, bankers and doctors. And by removing people from some of the reinforcements for their heritage, as well as from the constraints (including surveillance exercised by kin and neighbours) on alternative types of behaviour, separation could also lead to changes in behaviour, norms and 
aspirations on the part of both the migrant and those in the migrant's kin and friendship networks.

Increased economic well-being in consequence of migration could, for example, raise one's social status, remove the burden of debt or open up opportunities for schooling, training or entrepreneurship - each capable of enhancing self-confidence and broadening the range of perceived possibilities. ${ }^{5}$ Improved economic condition, by enabling purchase of a radio, television set or car, for example, could also bring one into contact with certain elements of the wider, even international, society with resulting changes in outlook, levels of aspiration or self-awareness.

A wider range of contacts, greater or more meaningful contacts with others of possibly different values or behaviours, involvement with a new set of "significant others", whether brought about directly through personal contact or indirectly through contact with a migrant intermediary or greater access to the media of mass communication, for example, could extend the range of one's expectations and possibilities respecting behaviour, levels of aspiration, consumption, morals or values. But, by raising levels of aspiration, by creating wants that did not previously exist, these extended contacts could also raise the level of personal discontent and frustration - irrespective of their consequences for women's status. Kadioglu (1994: 548-9), for example, found that, although they had lost some of the fatalism that characterized them in the pre-migration setting, and had acquired more "individualistic, independent, risk-taking, initiative-laden behaviour patterns", Turkish women who had been "exposed to the migration experience", either by emigrating themselves or by remaining behind upon the emigration of their husbands, also experienced increased frustration if they were unable to find "appropriate outlets (jobs or social activities) outside the household in the return context". And because they thought of themselves as a separate group, these women also often experienced difficulty relating to neighbours who lacked the migrant experience. Improvements in status do not necessarily come cost-free.

The relevant experiences attending the migration of a close relative or friend for which we have information relate to whether the migration had any effect on the following:

a) The amount of care the non-migrant respondent extended to family members.

Question: Did [your husband/wife's; this person's/these persons' absence(s)] have much effect on your responsibilities for taking care of other family members? For instance, did it cause you to start or stop looking after an aged parent or a grandchild?

b) The non-migrant's responsibilities concerning family property. 
Question: Did [it/they] have much effect on your responsibilities for taking care of a family property or enterprise? For instance, did it cause you to do more or less work - or do a different kind of work - in connection with taking care of a house, farm, or family business?

c) The non-migrant's income.

Question: Did it increase your income, decrease it, or leave it at about the same level? Did it make your income more regular or less regular?

d) The non-migrant's social activity.

Question: Did it affect your social activity - i.e., the things you did, the people you visited with? For instance, did it increase or decrease the frequency with which you visited friends or relatives? The amount of shopping you did/do on your own?

e) Composition of the non-migrant's household.

Question: Did it affect the composition of your household - whether, for example, you moved to or combined with another household?

f) The non-migrant's living conditions.

Question: Did it affect your living conditions - that is, your housing, your furnishings, your household equipment, for example?

If migration does affect the status of women through socialization, those in different categories with respect to whether or not they were affected in these various ways, could be expected to manifest different patterns of responses respecting the presumed indicators of the status of women.

The limitation that the small Ns posed to this kind of analysis was aggravated by our having to control for Sex, Age, and Schooling because of the strong association of each of these characteristics with the pattern of responses on these variables. It was aggravated still further by our deciding, in an effort to avoid some of the worst biases to be anticipated with small Ns, that, in searching for patterns, the prudent course was to confine ourselves to comparisons between cells containing at least 4 respondents. This meant having to exclude: by urban-rural Residence, all men living in rural areas; by Age, all men under 35; and, by Schooling, all men in both the no schooling and secondaryfirst level categories, as well as all women in the tertiary category.

Our approach was to cross-tabulate (a) the answers of the non-migrants in the migrants' close kin and friendship networks regarding certain individual variables presumed to be indicative of the status of women (e.g., whether it is a good thing for women to cover their hair, whether it is all right for unmarried women to have boyfriends) with (b) certain of their experiences associated with the migration of close kin that we presumed to be determinative of views relevant to the status of women (e.g., whether the migration caused them to start 
looking after an aged parent, whether it increased the frequency of visiting friends or relatives, or of shopping on their own), while controlling (c) for sex and (d) separately for urban-rural residence, age and schooling. We hypothesized that one or another of these experiences, because of their presumed significance to the development of, for example, new skills, new aspirations, or greater self-confidence, would be associated with expressing a more "modern", "progressive" view on matters presumably indicative of the status of women.

Contrary to what might be anticipated on the basis of the "modernization" theories promulgated, for the most part, in the 1950s and 1960s (e.g., Lasswell, 1951; Lerner, 1958; Coleman, 1960; Rostow, 1960; McClelland, 1961; Hagen, 1962), what we found was less consistency than variety. Only among rural women is there a consistent pattern in such a direction; while among urban men - with an almost equal degree of consistency - the pattern is in the opposite direction (Table 6, pages 368-369). Elsewhere, the patterns are mixed. Comparisons by age and schooling (controlling for sex in each instance) show rather more frequent support for the hypothesis among women than among men. Nonetheless, the overall pattern is one of inconsistency - the hypothesis receiving less support here, more support there. There are two exceptions: among women, a decline with increased schooling in the proportion of comparisons showing non-support for the hypothesis, and, among men, a somewhat less regular association in the opposite direction.

Among specific experiences, the pattern is also mixed, although experiences are more often associated with support for the hypothesis among women and, with non-support for it among men. The one exception (and it is among men and involves a relatively small number of comparisons) is with social activity, where an increase in consequence of the migration of a close kinsperson or friend is considerably more likely to lead to the expression of more "modern", "progressive" views.

Nor is there much variation in the pattern associated with the various experiences resulting from this person's migration. Social activity aside, the proportion of comparisons in which a more "modern" view is expressed ranges, among men, only from 25 to 32 per cent. The variation among women is greater; but still only from 46 to 70 per cent - and from only 46 to 62 per cent if that 70 per cent outlier is omitted.

Among the various presumed indicators of women's status, comparisons among women show a consistent association between having these experiences and a higher proportion expressing a "modern" view. But the differences are not particularly large. They extend only from 10 percentage points (concerning the acceptability of women covering their hair) to 31 percentage points (concerning whether a woman should be able to choose her husband over the 
objection of her father). Among men the pattern is one of variation. With some indicators (e.g., women covering their hair, access of an unmarried woman to abortion, choice of husband, whether employed married women should decide how their earnings are to be spent), support for the hypothesis in association with having one or the other of these experiences is less frequent than nonsupport, and with others (e.g., permissibility of an unmarried woman having a boyfriend, or living alone, or having access to contraception), it is more frequent than non-support. But the ranges where non-support for the hypothesis is more frequent are sizeable (from 31 per cent with respect to choosing a husband to 56 per cent with respect to whether an employed married woman should determine how her earnings are spent), while those where support for the hypothesis is more frequent extend only from 5 to 8 percentage points.

\section{CONCLUSION}

International migration of the type engaged in by Turks during the last few decades has doubtless improved the strictly economic position in the home country of both the returned migrants and, through remittances, those in their close networks. This has been abundantly documented. Whether this is of any lasting benefit either to the migrants and their networks, or to the society from which they come, is at the least a debatable point, the resolution of which depends essentially on the length of time under consideration and the criteria employed. For example, three quarters of the 81 respondents in the present study who had not themselves migrated said that, because of the migration of a close relative, they had bought things they would not otherwise have been able to buy. They also reported that these purchases had produced friction between themselves and their neighbours, friends or relatives. Migration of this type can also occasion considerable amounts of personal frustration, sorrow and discontent - as well as, on occasion, of hope, response, joy and happiness. This, too, has received considerable documentation, though not as much as that attending the narrowly economic consequences.

But what of rather more social consequences - specifically, in the present instance, the status of women? One might suppose that "modernization" theory would have some bearing on the issue. Whether explicitly or merely by implication, it consistently presents a rise in women's status - economic, political, and social - as being elemental to modernization; and widely employs indicators of such a rise as measures of the extent of modernization (e.g., McClelland, 1961:399).

But while still widely applied in demographic studies (Szreter, 1993; Greenhalgh, 1996), modernization theory has been rightly criticized as excessively grounded in the characteristically narrow analytical framework of 
neo-classical economics, culturally-biased in favour of Westernization, unrealistically unilinear, and blind to socially specific differences between men and women in goals, behaviour and experience. ${ }^{6}$ As noted recently by one of the more perceptive of its critics (Kabeer, 1994: xiv-xv):

\begin{abstract}
Neo-classical economics provides a powerful illustration of the gender-blindness of development thought in general because it epitomizes more than any other discipline the reductionist procedures through which issues of power and inequality have been kept out of the mainstream social sciences.... The model of human behaviour that economists offer is austere, abstract and formal, totally devoid of the ambiguity, conflicts, noise and mess which characterize the world as we know it, and play a more important role in the more empirically grounded approaches to social reality....[E]conomists have generally disposed of feminist concerns with gender power and conflict through the breathtakingly simple device of assuming that they do not exist; their preoccupation with measurability ensures that such issues do not emerge at any subsequent empirical stage of analysis.
\end{abstract}

Whatever the term applied to the condition towards which so much social change in today's world seems to be heading - "development", "free market capitalism", "modernization", "Westernization" - the process is assuredly far more complex, and by no means as consistently unilinear, as earlier modernization theorists have implied. As modernization theory would predict, our data show a consistent association between migrant status and the holding of views presumably indicative of such status - with "modern", "progressive" views being expressed most often by the returned migrants and least often by the control group. And while schooling and age are also associated with the likelihood of holding such views - positively so in the case of schooling and generally negatively so in the case of age - the association with migrant status continues to hold when schooling and age are controlled for.

In contrast to what could be anticipated from modernization theory, the results of our attempts to determine whether the association with migrant status was due essentially to recruitment or to socialization associated with the experience of migration, suggest that recruitment is highly significant, while the returns on socialization are decidedly mixed. Support for the view that migration results in a higher status for women coexists with support for the view that it makes no difference or even that it results in a lower status.

One source of difficulty could be that we have been working with mere indicators of status, and not with such actual components of status as: (a) the treatment accorded women by their fathers, brothers, husbands, or men in general; (b) the extent to which women enjoy equality with men before the law; or (c) the degree of control over their own activities (e.g., freedom of movement, determination of what one can do with one's body, opportunities for 
one's personal development) that women enjoy relative to men. However, if men and women are holding different viewpoints about matters affecting women - even if, in specific instances, they are not themselves directly affected - that, in itself, can result in a changed status for women.

There is also the possibility of ambiguity with one or another of our measures. Concerning the acceptability of women covering their hair, for instance, it is interesting to note Ibrahim's (1982: 19) views in relation to a "modern" role in Arab countries:

The veiled medical student represents a complicated response to a complicated world around her - a world over which she has no control. That world includes an influx of foreigners, oil wealth, expensive consumer goods, high inflation, and "alien" life-styles. Despite her superb achievements in examinations, she finds herself overwhelmed, estranged, and insignificant in a big, impersonal urban world. Clinging to a "heritage" seems to restore her feeling of worth, protect her against the unknown, and lessen the alienation she feels....It is [her] way of imposing a semblance of order on an otherwise chaotic world (see also Hoodfar, 1993).

On a related point, pertaining to men as well as women, Salt (1995) sees the recent rise of the fundamentalist Muslim Refah party in Turkey as being largely a response to dissatisfaction with the government's socially costly (albeit modern) laissez-faire economic policies and its encouragement of Western influences. Muslim fundamentalism, he concludes, provides a sense of belonging to masses increasingly impoverished by economic policies that have resulted in high unemployment and falling wages. Similar conclusions have been reached concerning the rise of religious fundamentalism in the West. In referring to the late 18th century, Sandeen (1970: xvi) sees "the mood of the Protestant evangelicals [changing] in response to the tensions of industrialization and immigration from one of cocky optimism to chastened uncertainty", while Misztal and Shupe (1992: 4-5) argue that "religious fundamentalism is an instant heuristic remedy to the situation of rapid change, frequently the change that is posed from without or from above".

Something of what Herf (1984) has termed "reactionary modernism" could well be at work: exposure to modern economic and social forces not invariably leading - as modernization theory would have it - to free markets, parliamentary democracy and the ideal of equality before the law but, in many instances, to a rejection of such values and a renewed commitment to traditional ways. Lasswell (1951: 6), at least, recognized the possibility:

Until recently, it was not fantastic to imagine that the next few decades would mark the triumph of free societies throughout the globe. Today it must be conceded that anti-progressive tendencies may win out. 
Nor are economically advanced countries necessarily immune. Luker (1984:159-175), in her intensive interviewing, mostly in California, of a large selection of "pro-life" and "pro-choice" activists, found a number of women actively opposing abortion because, whether or not it was fully articulated, they considered their best chance for a good life to lie in a conventional, traditional family - which they perceived to be profoundly threatened by abortion. Hochschild and Machung, perceiving the existence of "a 'his' and 'hers' of industrialization" (p. xvi), argue that, so far as the status of women is concerned, the United States, at least, is in a "stalled revolution" in which women have lost some of the traditional protections of patriarchy without attaining a compensatory degree of full equality (1989: 11-17). Although their argument is based on the consequences seen as flowing from increased employment of married women outside the home, it does not seem unlikely that male-female relations could be similarly affected by the types of modernization-related changes that involve women in Turkey: greater independence of movement and exposure to urban or foreign-based mass media, with the consequent changes in women's attitudes, or even in their power position relative to men, evoking from men a reactive, defensive response of a kind that places greater value on the retention of more traditional ways. Modernization is a complex, often highly disruptive experience; keeping women "in their place" could, for some (both men and women) appear to be a sound and acceptable strategy for managing these disruptions. The assumption that modernization will inevitably improve the status of women, and that this improvement is something invariably desired by men and women alike, is, at the least, a matter that should be carefully scrutinized.

What one sees most clearly in these Turkish data is a considerable diversity of viewpoints among people within the same presumably socially-significant sectors of the population (i.e., within the same age/sex/residence/schooling sectors) about certain matters pertaining to the status of women. Some of this diversity is doubtless associated with the experience of migration, both direct and indirect. But there is also evidence of a society in the process of rapid change: undergoing rapid urbanization, experiencing sizeable increases in the numbers of automobiles and certain other consumer items (with all the pressures for changing lifestyles and values these bring with them), and also experiencing a rapid extension of literacy, marked expansion of both the knowledge and practice of birth control (including abortion) and a concomitant reduction in fertility. Then there is the growth of Muslim fundamentalism, as well as the troubles with Kurdish separatists.

There can be no doubt that migration is causally associated with some of these changes. The increased numbers of automobiles and other consumer items are a particularly obvious example, and, as already noted, some see a causal connection between migration and the growth of Muslim fundamentalism. But it is these more general social changes, not migration as such, that seem likely 
to have greater bearing on the status of women. There is little support here for the contention that the type of international migration that has involved so many Turks these past three decades, mostly temporary and economically motivated, and from relatively poor agricultural or slightly industrialized areas to rich, highly industrialized ones characterized by marked differences in language, religion, and overall culture, is going to result in moving the status of women from a more to a less "traditional" plane.

\section{NOTES}

1. We gratefully acknowledge the helpful comments on an earlier draft by Professor Kristin Luker, and also the collegial encouragement and persevering administrative support of Professor Gavin Jones.

2. In Ankara, Yasa's (1969) study of six localities; in Konya, Engelbrektsson's (1978) and Alpay and Sariaslan's (1984) studies of the small district town of Kulu; and in Yozgat, Abadan-Unat et al.'s 1975 study (published in 1976) of the Bogazliyan district.

3. They were selected from more than 25 applicants recruited by the Director of Fieldwork through his contacts with various social science departments at two universities in Ankara: Bilkent University and Middle East Technical University. Three of the interviewers (two men and one woman) were social science graduate students with interviewing experience; two women interviewers were social science graduates, and the male interviewer (husband of one of the interviewers) was an electronic engineer. They also participated in discussion on construction of the questionnaire and in the development of indicators of "traditional" and "modern".

4. A successful application of the same approach can be found in L.H. Day (1991).

5. Were economic wellbeing to decline - a not uncommon experience among migrants - the exact opposite could ensue.

6. Greenhalgh credits Tipps (1973) with writing the "seminal" critique of the theory.

\section{REFERENCES}

Abadan-Unat, N., et al.

1976 Migration and Development, A Study of the Effects of International Labour Migration on Bogazliyan District, NUFFIC (Netherlands Universities Foundation for International Cooperation) and IMWOO (Institute for Social Science Research in Developing Countries), The Hague, and Institute of Housing, Urban and Regional Development, Faculty of Political Science, Ankara University, Ankara.

Alpay, S., and H. Sariaslan

1984 Effects of Emigration: The Effects on the Town of Kulu in Central Turkey of Emigration to Sweden, Commission for Immigrant Research Sweden, Swedish Government Printing, Stockholm. 
Appleyard, R.T.

1989 "Migration and development: myths and reality", International Migration Review, 23(3): 486-499.

Azmaz, A.

1984 Migration and Reintegration in Rural Turkey - The Role of Women Behind, Edition Herodot, Göttingen.

Bennett, B.C.

1979 "Migration and rural community viability in central Dalmatia (Croatia), Yugoslavia”, Papers in Anthropology, 20(1): 75-83.

Bocker, A.

1995 "Migration networks: Turkish migration to Western Europe", in R. Erf and

L. Heering (Eds), Causes of International Migration, Office for Official Publications of the European Communities, Luxembourg.

Coleman, J.S.

1960 "Conclusion: the political system of the developing areas", in G.A. Almond and J.S. Coleman (Eds), The Politics of the Developing Areas, Princeton University Press, Princeton.

Day, A.T.

1985 “We Can Manage” - Expectations about Care and Varieties of Family Support among People 75 Years and Over, Institute of Family Studies, Monograph No. 5, Melbourne.

1991 Remarkable Survivors - Insights into Successful Aging among Women, Urban Institute Press, Washington.

Day, L.H.

1991 "Is there any socially significant psychological difference in being an only child? - The evidence from some adult behavior", Journal of Applied Social Psychology, 21: 754-773.

Du Toit, B.M.

1975 "Introduction: migration and population mobility", in B.M. Du Toit and H.I. Safa (Eds), Migration and Urbanization: Models and Adaptive Strategies, Mouton, The Hague.

Du Toit, B.M., and H.I. Safa (Eds)

1975 Migration and Urbanization: Models and Adaptive Strategies, Mouton, The Hague.

Engelbrektsson, U.-B.

1978 The Force of Tradition: Turkish Migrants at Home and Abroad, Acta Universitatis Gotheburgensis, Göteborg, Sweden.

Gökdere, A.

1994 "An evaluation of Turkey's recent migration flows and stocks", The Turkish Journal of Population Studies, 16: 29-56.

Gordon, E.

1978 The Women Left Behind: A Study of the Wives of the Migrant Workers of Grasmuck, S. Lesotho, ILO World Employment Working Paper no. 35, Geneva.

1982 "The impact of emigration on national development: three sending communities in the Dominican Republic", Occasional Paper no. 33, Center for Latin American and Caribbean Studies, New York University, New York, (mimeo). 
Greenhalgh, S.

1996 "The social construction of population science: an intellectual, institutional, and political history of twentieth-century demography", Comparative StudGulick, J. ies in Society and History, 38: 26-66.

1976 The Middle East: An Anthropological Perspective, Goodyear Publishing Co., Pacific Palisades, California.

Gunatilleke, G. (Ed.)

1992 The Impact of Labour Migration on Households: A Comparative Study in Seven Asian Countries, United Nations University Press, Tokyo.

Hagen, E.E.

1962 On the Theory of Social Change: How Economic Growth Begins, Dorsey Press, Homewood, Illinois.

Herf, J.

1984 Reactionary Modernism: Technology, Culture and Politics in Weimar and the Third Reich, Cambridge University Press, Cambridge.

Hochschild, A., and A. Machung

1989 The Second Shift, Viking, New York.

Hoodfar, H.

1993 "The veil in their minds and on our heads: the persistence of colonial images of Muslim women", Resources for Feminist Research, 22: 5-18.

Hugo, G.J.

1978 Population Mobility in West Java, Gadja Mada University Press, Indonesia. Ibrahim, S.E.

1982 The New Arab Social Order: A Study of the Social Impact of Oil Wealth, Croom Helm, London, and Westview Press, Boulder, Colorado. Içduygu, A.

1991 "Migrant as a Transitional Category: Turkish Migrants in Melbourne, Australia", unpublished PhD thesis, Department of Demography, Australian National University, Canberra.

Kabeer, N.

1994 Reversed Realities: Gender Hierarchies in Development Thought, Verso, New York and London.

Kadioglu, A.

1994 "The impact of migration on gender roles: findings of field research in Turkey", International Migration, 32(4): 533-560.

Khafagi, F.

1983 "Socio-economic impact of emigration from a Giza village", in A. Richards and P.L. Martin (Eds), Migration, Mechanization, and Agricultural Labor Markets in Egypt, Westview Press, Boulder, Colorado.

Khattab, H.A.S., and S.G. El Daeif

1982 Impact of Labor Migration on the Structure of the Family and the Roles of Women, The Population Council, West Asia and North Africa Region, Giza, Egypt.

Lasswell, H.D.

1951 The World Revolution of Our Time, Stanford University, Hoover Institute Studies, Series A: General Studies, No. 1, Stanford University Press, Palo Alto, California. 
Lerner, D.

1958 The Passing of Traditional Society, Free Press, Glencoe, Illinois.

Luker, K.

1984 Abortion and the Politics of Motherhood, University of California Press, Berkeley.

McArthur, H.J., Jr.

1979 "The effects of overseas work on return migrants and their home communities: a Philippine case", Papers in Anthropology, 20: 85-104.

McClelland, D.C.

1961 The Achieving Society, D. Van Nostrand, New York.

Misztal, B., and A. Shupe

1992 "Making Sense of the Global Revival of Fundamentalism", in B. Misztal and A. Shupe (Eds), Religion and Politics in Comparative Perspective, Praeger, Westport, Connecticut.

Morauta, L.

1984 Left Behind in the Village: Economic and Social Conditions in an Area of High Outmigration, Monograph 25, Institute of Applied Social and Economic Research, Boroko, Papua New Guinea.

Rhoades, R.

1979 "From caves to main street: return migration and the transformation of a Spanish town", Papers in Anthropology, 20(1): 57-74.

Rostow, W.W.

1960 The Stages of Economic Growth, Cambridge University Press, Cambridge. Salt, Jeremy

1995 "Nationalism and the rise of Muslim sentiment in Turkey", Middle Eastern Studies, 31: 13-27.

Sandeen, E.R.

1970 The Roots of Fundamentalism: British and American Millenarianism 18001930, University of Chicago Press, Chicago.

SOPEMI-OECD (Organisation for Economic Co-operation and Development)

1988 Continuous Reporting System on Migration, 1987, Paris.

Szreter, S.

1993 "The idea of demographic transition and the study of fertility: a critical intellectual history", Population and Development Review, 19: 659-701.

Tipps, D.C.

1973 "Modernization theory and the comparative study of societies: a critical perspective", Comparative Studies in Society and History, 15: 199-226.

Yasa, I.

1969 Yirmibes Yil Sonra Hasanoglan Köyü, Ankara University, Ankara. Yenisey, L.

1976 "The social effects of migrant labour on the district left behind: observations in two villages of Bogazliyan", in N. Abadan-Unat (Eds), Migration and Development: A Study of the Effects of International Labour Migration on Bogazliyan District, The Hague, and Institute of Housing, Urban and Regional Development, Faculty of Political Science, Ankara University, Ankara. 
TABLE 1

MIGRANT STATUS AND OPINIONS RELEVANT TO THE STATUS OF WOMEN: BEHAVIOUR (per cent)

\begin{tabular}{|c|c|c|c|}
\hline & $\begin{array}{c}\text { Returned } \\
\text { migrant }\end{array}$ & $\begin{array}{l}\text { Close kin/ } \\
\text { friend }\end{array}$ & Control \\
\hline$[N=$ & 83 & 107 & $44]$ \\
\hline
\end{tabular}

1. What do you think about women covering their hair? Do you think it's a good idea, a bad idea, or doesn't it really matter?

Good idea

2. In general, do you think it's all right for an unmarried man to have girlfriends?

No

3. In general, do you think it's all right for an unmarried woman to have boyfriends?

$$
\text { No }
$$

4. Do you think it's all right for an unmarried woman to live by herself if she wants to?

No 
TABLE 2

MIGRANT STATUS AND OPINIONS RELEVANT TO THE STATUS OF WOMEN:

MORALS (per cent)

\begin{tabular}{|c|c|c|c|c|}
\hline & & $\begin{array}{l}\text { Returned } \\
\text { migrant }\end{array}$ & $\begin{array}{l}\text { Close kin/ } \\
\text { friend }\end{array}$ & Control \\
\hline \multicolumn{5}{|c|}{ Question } \\
\hline 5. & $\begin{array}{l}\text { Do you think it's all right for married } \\
\text { women to use contraception? } \\
\text { [If YES] Is it all right if their husbands } \\
\text { don't know about it? }\end{array}$ & & & \\
\hline & No, not even if husbands know & 7 & 17 & 43 \\
\hline 6. & $\begin{array}{l}\text { In some countries, unmarried women } \\
\text { are allowed to use contraception. } \\
\text { What about this for Turkey? Do you } \\
\text { think unmarried women in Turkey } \\
\text { should be allowed to use } \\
\text { contraception? }\end{array}$ & & & \\
\hline & No & 55 & 68 & 96 \\
\hline \multirow[t]{2}{*}{7.} & $\begin{array}{l}\text { Do you think a married women should } \\
\text { be allowed to obtain an abortion? } \\
\text { [If NO] Even if the pregnancy threatens } \\
\text { her health? }\end{array}$ & & & \\
\hline & Yes, unqualified & 55 & 44 & 27 \\
\hline \multirow[t]{2}{*}{8.} & $\begin{array}{l}\text { What aboutunmarried women? } \\
\text { Should an unmarried woman be } \\
\text { allowed to obtain an abortion? } \\
\text { [lf NO) Even if the pregnancy is the } \\
\text { result of rape? Even if the pregnancy } \\
\text { threatens her health? }\end{array}$ & & & \\
\hline & Yes, unqualified & 34 & 26 & 7 \\
\hline
\end{tabular}


TABLE 3

MIGRANT STATUS AND OPINIONS RELEVANT TO THE STATUS OF WOMEN: OPPORTUNITY (per cent)

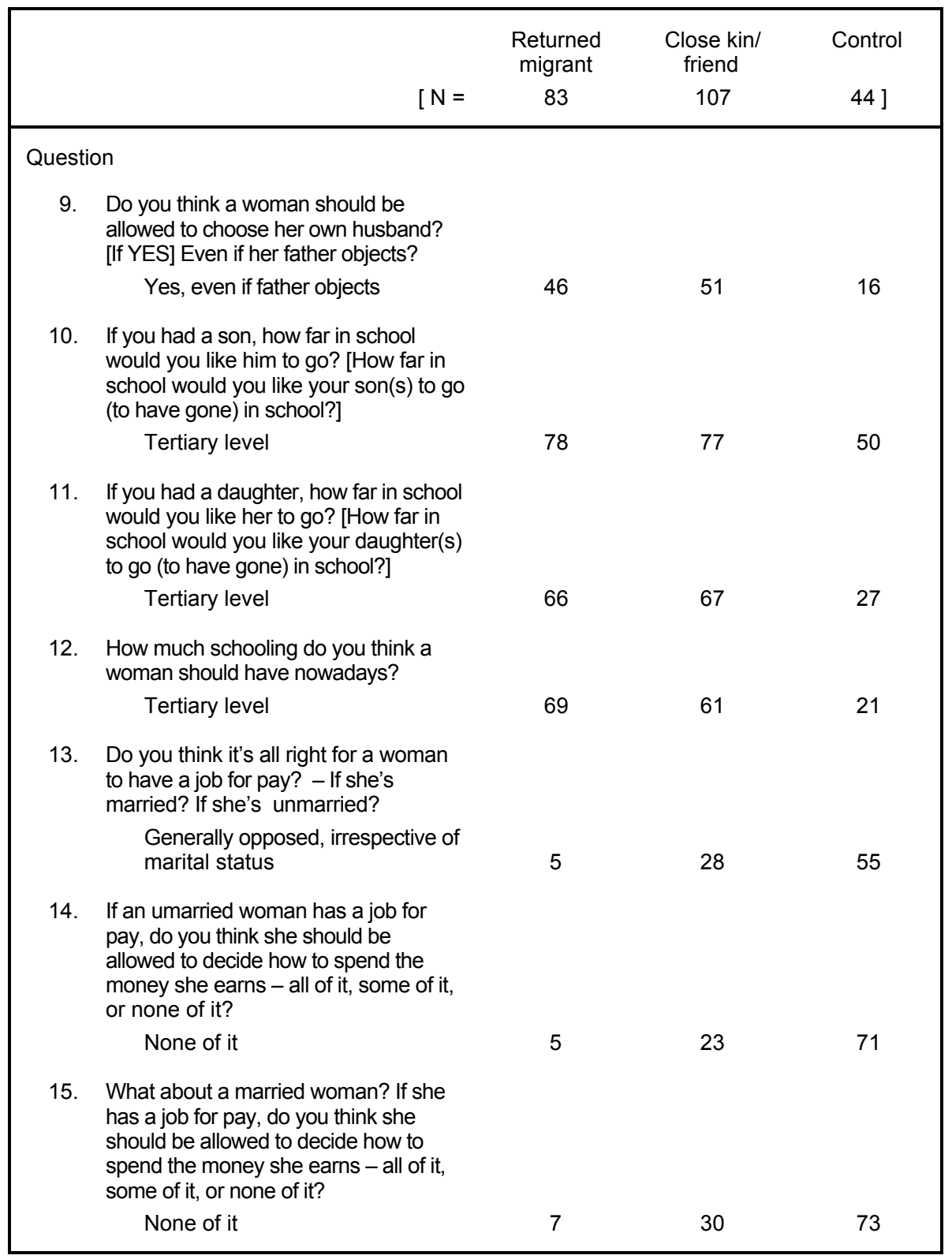


TABLE 4

EXAMPLES OF TABULATIONS WTH CONTROLS FOR SEX AND AGE

\begin{tabular}{|c|c|c|c|c|c|c|c|c|c|c|c|c|}
\hline & \multicolumn{3}{|c|}{ Under 35 years } & \multicolumn{3}{|c|}{$35-47$ years } & \multicolumn{3}{|c|}{48.54 years } & \multicolumn{3}{|c|}{$56+$ years } \\
\hline & Migrant & Kin & Control & Migrart & Kin & Contral & Migrant & Kin & Contral & Migrant & $\mathrm{Kin}$ & Contral \\
\hline \\
\hline Males & 4 & 6 & -0 & 11 & 11 & 9 & 17 & 7 & 11 & 15 & 2 & 4 \\
\hline Females & 3 & 2 & 5 & 11 & 25 & 4 & 13 & 23 & 7 & 9 & 10 & 4 \\
\hline \multicolumn{13}{|l|}{ Questions: } \\
\hline \multicolumn{13}{|c|}{3 In genaral do you think if's all right for an unmarried woman to have boytriends? } \\
\hline & \multicolumn{12}{|c|}{ PERCENTAGE ANSWERING NO } \\
\hline Males & $\mathbf{z}$ & 3 & - & 5 & 2 & 78 & $n$ & $\infty$ & ท & 60 & 50 & 100 \\
\hline Females & -0. & 17 & 100 & 36 & $\dot{\theta}$ & 100 & 3 & 74 & 8 & 33 & 100 & 100 \\
\hline \multicolumn{13}{|c|}{ 5. Do you think it's all night for married women to use contracapton? [f YES] is it al. right if ther husbands don't know about it? } \\
\hline & \multicolumn{12}{|c|}{ PERCENTAGE ANSWERING YES, WHETHER OR NOT HUSBANDS KNOW } \\
\hline Males & 100 & 5 & . & 30 & 9 & -0 & 24 & 14 & 9 & 13 & $-\infty$ & -0. \\
\hline Females & $1 \omega$ & 57 & 20 & 5 & 32 & -0 - & 54 & 35 & 14 & 22 & 30 & 25 \\
\hline \multicolumn{13}{|c|}{ Gon. What about this for } \\
\hline \multicolumn{13}{|c|}{ PERCENTAGE ANSWERING NO } \\
\hline Males & 50 & 50 & - & 18 & 82 & 100 & 18 & 100 & 91 & 53 & 50 & 100 \\
\hline Females & -0 & 35 & 100 & 45 & 72 & 100 & $\pi$ & 74 & 86 & 56 & 100 & 100 \\
\hline
\end{tabular}


TABLE 4 (continued)

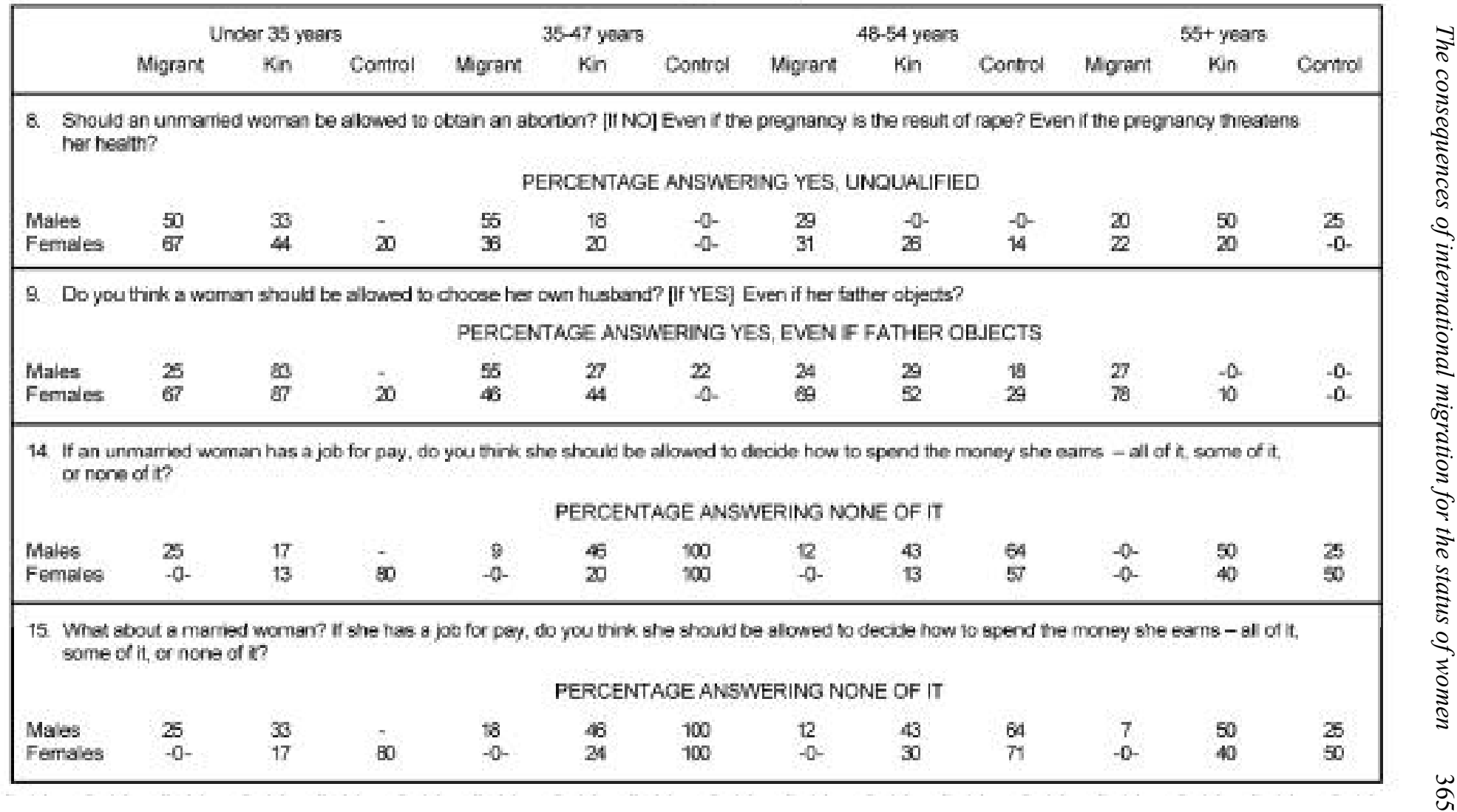


TABLE 5

EXAMPLES OF TABULATIONS WITH CONTROLS FOR SEX AND SCHOOLING

\begin{tabular}{|c|c|c|c|c|c|c|c|c|c|c|c|c|c|c|c|}
\hline & \multicolumn{3}{|c|}{ Nore } & \multicolumn{3}{|c|}{ Primary } & \multicolumn{3}{|c|}{ Secondary-1 } & \multicolumn{3}{|c|}{ Secondary-2 } & \multicolumn{3}{|c|}{ Tertiary } \\
\hline & Mg & Kin & Con & Mig & Kn & Con & $\mathrm{Mig}$ & Kin & Con & $M i g$ & $\mathrm{Kin}$ & Con & Mig & Kin & $\mathrm{Con}$ \\
\hline \\
\hline Males & -0 & -0 . & 1 & 21 & 6 & 6 & 10 & 4 & 14 & 8 & 10 & 3 & 7 & 6 & $-0-$ \\
\hline Females & 7 & 8 & 5 & 18 & 35 & 9 & 3 & 18 & 4 & 8 & 12 & 2 & -0 & 8 & $-0-$ \\
\hline \multicolumn{16}{|l|}{ Questions: } \\
\hline \multicolumn{16}{|c|}{ his for Turker? Do you trink unmamed women in Turkey should } \\
\hline & \multicolumn{15}{|c|}{ PERCENTAGE ANSWERING YES } \\
\hline Males & $=$ & $=$ & -0 & 19 & -0 - & -0 & 20 & -0 & -0 & 11 & 30 & -0 & 71 & 50 & - \\
\hline Females & 14 & 25 & -0 - & 28 & 8 & -0 & -0 . & 28 & -0 & 88 & 42 & -0 & $\because$ & 88 & - \\
\hline \multicolumn{16}{|c|}{ 7. Do you think a married woman should be allowed to oblain an abertion? [H NO| Even if the pregnancy theaters her heattr? } \\
\hline & \multicolumn{15}{|c|}{ PERCENTAGE ANSWERING YES, WITHOUT QUALIFICATION } \\
\hline Males & : & $=$ & 0. & 43 & 17 & 17 & 50 & 25 & 21 & 56 & 50 & 33 & 57 & 50 & - \\
\hline Females & -0 & 13 & 40 & 61 & 40 & 33 & 67 & 56 & 0 . & (20) & 80 & 100 & 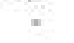 & 26 & . \\
\hline
\end{tabular}


TABLE 5 (continued)

\begin{tabular}{|c|c|c|c|c|c|c|c|c|c|c|c|c|c|c|c|}
\hline & \multicolumn{3}{|c|}{ None } & \multicolumn{3}{|c|}{ Primary } & \multicolumn{3}{|c|}{ Secondary-1 } & \multicolumn{3}{|c|}{ Secondary-2 } & \multicolumn{3}{|c|}{ Tertiary } \\
\hline & Mig & Kin & Con & Mig & Kin & Con & Mig & $\mathrm{Kn}$ & Con & $\mathrm{Min}$ & $\mathrm{Kn}$ & Con & $\mathrm{Mig}$ & Kin & Con \\
\hline \multicolumn{16}{|c|}{ 2. Do you think a woman shouid be allowed to choose her own husband? [f YES] Even if her father objects? } \\
\hline & \multicolumn{15}{|c|}{ PERCENTAGE ANSWERING YES, EVEN IF FATHER OBJECTS } \\
\hline Males & - & - & -0 . & 3 & 33 & -0 . & 10 & 25 & 21 & 33 & 20 & 33 & 57 & 83 & - \\
\hline Females & 43 & $\mathbf{B}$ & 20 & 67 & 49 & 11 & G & 50 & -0 & 75 & 5 & 50 & - & 100 & - \\
\hline \multicolumn{16}{|c|}{ 13. Do you thirk it's all right for a wornan to have a job for pay? - If she's married? if shes unmamed? } \\
\hline & \multicolumn{15}{|c|}{ PERCENTAGE GENERALY OPPOSED, IRFESPECTIVE OF MARITAL STATUS } \\
\hline Males & *. & $=$ & -0 & 19 & 50 & 50 & $=0$ & $\pi$ & 71 & $=0$ & 20 & 67 & $=0$ & 17 & - \\
\hline Femsles & -0 & 50 & $\infty 0$ & 67 & 37 & 33 & $=0$ & 17 & 75 & -0 & 8 & -0 & $=$ & -0 & - \\
\hline \multicolumn{16}{|c|}{$\begin{array}{l}\text { 14. If an unmaried woman has a job for pay, do you think she should be allowed lo decide how to spend the money she eams - al of it, some of it, } \\
\text { or none of in? }\end{array}$} \\
\hline & \multicolumn{15}{|c|}{ PERCENTAGE ANSWERING NONE OF IT } \\
\hline Males & - & - & -0 & 5 & 50 & 50 & 20 & 100 & 86 & 11 & 30 & $6 \pi$ & -0 & -0 & - \\
\hline Females & -0 & 50 & 60 & -0 & 23 & 89 & -0 & 17 & 75 & -0 & $-0-$ & -0 & - & -0 & - \\
\hline
\end{tabular}


TABLE B

PERCENTAGE OF NON-MIGRANTS EXPRESSING MORE "PROGRESSIVE" VIEWS ON SELECTED INDICATORS

OF STATUS OF WOMEN, BY WHETHER EXPERIENCED SPECIFIED CHANGES AS RESULT OF EMIGRATION OF CLOSE KIN OR FRIEND: RURAL WOMEN AND URBAN MEN

\begin{tabular}{|c|c|c|c|c|c|c|c|c|}
\hline \multirow[b]{3}{*}{ Rural Women } & \multirow[b]{3}{*}{$\mathrm{N}$} & \multicolumn{7}{|c|}{ Indicators of Stahs of Women } \\
\hline & & \multirow[b]{2}{*}{$\begin{array}{l}\text { Cover } \\
\text { har }\end{array}$} & \multicolumn{5}{|c|}{ Unmarned woman } & \multirow[b]{2}{*}{$\begin{array}{l}\text { Emplayed wife determins } \\
\text { use eamings }\end{array}$} \\
\hline & & & Boyfriend & Live abone & $\begin{array}{l}\text { Ad } \\
\text { Contra: } \\
\text { ception }\end{array}$ & Aboriton & $\begin{array}{l}\text { Chocse } \\
\text { husband }\end{array}$ & \\
\hline \multicolumn{9}{|l|}{ Care of relative } \\
\hline Nocharge & 14 & 50 & 71 & 86 & 14 & 14 & 3 & $x$ \\
\hline Increased & 8 & 13 & 36 & 50 & 30 & $\pi$ & 2 & 3 \\
\hline \multicolumn{9}{|l|}{ Care of properthbueiness } \\
\hline No change & 11 & 55 & 73 & 82 & 18 & 78 & 6 & ש \\
\hline Increased & 13 & 8 & 45 & 46 & 39 & 31 & $\theta$ & 23 \\
\hline \multicolumn{9}{|l|}{ Income } \\
\hline Nochange & 7 & 71 & $\infty$ & 100 & -0 & -0 & 29 & 43 \\
\hline hcressed & 20 & 15 & 50 & 50 & 40 & 35 & 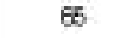 & 20 \\
\hline \multicolumn{9}{|l|}{ Social activity } \\
\hline Increased & 17 & 6 & 47 & 41 & 47 & 41 & 65 & 18 \\
\hline \multicolumn{9}{|l|}{ Household } \\
\hline No chenge & 8 & 28 & 61 & $\pi 8$ & $\not 28$ & 28 & 4 & $\boldsymbol{\theta}$ \\
\hline Larger or compositon changed & 9 & 22 & 56 & 30 & 33 & $\underline{22}$ & 67 & 11 \\
\hline \multicolumn{9}{|l|}{ Living condifons } \\
\hline Noctienge & 7 & 71 & क6 & 100 & -0 & $-0-$ & 29 & 43 \\
\hline Improved & 20 & 10 & 50 & 50 & 40 & 35 & 60 & $\boldsymbol{\omega}$ \\
\hline
\end{tabular}

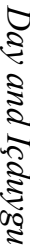


TABLE 6 (continued)

\begin{tabular}{|c|c|c|c|c|c|c|c|c|}
\hline \multirow[b]{3}{*}{ Urtean Men } & \multirow[b]{3}{*}{ N } & \multicolumn{7}{|c|}{ indicators of Status of Worrien } \\
\hline & & \multirow[b]{2}{*}{$\begin{array}{l}\text { Caver } \\
\text { har }\end{array}$} & \multicolumn{5}{|c|}{ Unmarried wornan } & \multirow[b]{2}{*}{$\begin{array}{c}\text { Emplayed wife determine } \\
\text { use earnings }\end{array}$} \\
\hline & & & Boyfriend & Live alone & $\begin{array}{l}\text { Ac } \\
\text { Contra- } \\
\text { ception }\end{array}$ & $\begin{array}{l}\text { ta } \\
\text { Abortion }\end{array}$ & $\begin{array}{l}\text { Chocese } \\
\text { husband }\end{array}$ & \\
\hline \multicolumn{9}{|l|}{ Care of relative } \\
\hline No change & 25 & {$[12]$} & 5 & 44 & 32 & [36] & $\underline{72}$ & -0 \\
\hline Increased & 10 & {$[10]$} & 44 & $\underline{90}$ & $\underline{\underline{20}}$ & {$[40]$} & $\underline{50}$ & $\underline{20}$ \\
\hline \multicolumn{9}{|l|}{ Care of propertybusiness } \\
\hline Nacharge & 28 & [14] & [54] & $\underline{57}$ & $\underline{\underline{x}}$ & 29 & 요 & 7 \\
\hline Increased & 7 & {$[14]$} & {$[57]$} & $\overline{71}$ & 14 & 57 & $\overline{43}$ & 14 \\
\hline \multicolumn{9}{|l|}{ Inoome } \\
\hline No charge & 15 & $\underline{-0 .}$ & 47 & 6 & 48 & 30 & 60 & {$[7]$} \\
\hline Increased & 20 & $\underline{\underline{E}}$ & $\underline{56}$ & 55 & $\underline{15}$ & 40 & 6 & {$[10]$} \\
\hline \multicolumn{9}{|l|}{ Social activity } \\
\hline Nacharge & 20 & $\underline{5}$ & $\underline{50}$ & BS & 36 & $\boldsymbol{z}$ & {$[\theta 0]$} & $\underline{5}$ \\
\hline Increased & 14 & $\underline{\underline{z}}$ & 64 & 64 & 14 & 43 & {$[64]$} & $\underline{5}$ \\
\hline \multicolumn{9}{|l|}{ Housahold } \\
\hline Nocharpe & 28 & 11 & 43 & 50 & 32 & 43 & $\pi$ & 7 \\
\hline Lager or compostion changed & 6 & $\underline{17}$ & B3 & 83 & $\underline{17}$ & $\underline{17}$ & $\underline{\underline{0}}$ & -0 \\
\hline \multicolumn{9}{|l|}{ Lving condfions } \\
\hline No changes & 2 & -0 & 25 & 50 & St & 25 & $\underline{75}$ & 8 \\
\hline Improved & 23 & $\underline{\underline{2}}$ & $\pi$ & $\underline{6}$ & 13 & 44 & 51 & 9 \\
\hline
\end{tabular}




\section{ETUDE TURQUE SUR L'IMPACT DE LA MIGRATION INTERNATIONALE SUR LA CONDITION FEMININE}

Dans le cadre d'une enquête plus large sur les conséquences de la migration pour ceux qui restent dans leur pays d'origine, 234 adultes vivant dans quatre provinces de Turquie ont été interrogés sur leurs opinions concernant la condition des femmes. Ils étaient répartis en trois catégories : (a) migrants revenus chez eux, (b) non migrants ayant un parent ou un ami proche immigré, (c) tous les autres. L'analyse contrôlée pour l'âge, le sexe, le lieu de résidence urbain/rural et le niveau d'instruction a montré que le groupe (a) a exprimé les opinions les moins traditionnelles et le groupe (c), les plus traditionnelles, le groupe (b) se situant à mi-chemin.

Des deux explications possibles de ce profil - le recrutement et la socialisation - le recrutement s'est avéré hautement significatif. En ce qui concerne la socialisation, par contre, les résultats étaient mitigés. La diversité considérable des opinions concernant le statut des femmes est sans aucun doute partiellement associée à l'expérience de la migration, qu'elle soit directe ou indirecte. Mais, il s'agit aussi d'une société en pleine évolution et ce sont ces changements sociaux rapides et plus généraux qui paraissent susceptibles d'affecter la condition féminine plutôt que la migration par elle-même.

Il y a peu de raisons de penser que le type de migration internationale où de si nombreux Turcs ont été impliqués au cours des trois dernières décennies - une migration temporaire et à motivation économique de régions agricoles ou faiblement industrialisées relativement pauvres vers des régions industrialisées caractérisées par des différences de langage, de religion et de culture en général - va entraîner une évolution des rôles féminins du plus vers le moins traditionnel. 


\section{LAS CONSECUENCIAS DE LA MIGRACION INTERNACIONAL PARA LA CONDICION DE LAS MUJERES: UN ESTUDIO TURCO}

Como parte de una investigación más amplia sobre las consecuencias de la migración internacional para las personas que permanecen en el país de origen, se entrevistó a 234 adultos en cuatro provincias turcas sobre temas relativos a la situación de las mujeres (principalmente solicitando sus opiniones). Se definieron tres categorías de migrantes: (a) los migrantes retornantes; (b) los conocidos o amigos no migrantes de migrantes y a título de control, (c) los demás. Habida cuenta de la edad, sexo, residencia urbana o rural y formación escolar, el grupo (a) tendía mayormente a expresar opiniones "no tradicionales", mientras que el grupo (c) tendía a expresar opiniones más bien tradicionales. El grupo (b) se situaba entre los dos.

De las dos explicaciones posibles para este patrón - contratación y socialización - se determinó que la contratación era altamente significativa, mientras que la prueba de socialización era sin lugar a dudas mixta. La gran diversidad de puntos de vista sobre la situación de las mujeres en esta encuesta está indudablemente asociada a la experiencia de la migración, ya sea directa o indirectamente. Además es representativa de una sociedad en proceso de cambio rápido; los cambios sociales más generales, y no la migración como tal, tienden a incidir en la situación de las mujeres. Es poco probable que la afirmación de que la migración internacional que ha concernido a tantos turcos durante estos últimos tres decenios - y que es mayormente de carácter temporal, con desplazamientos desde zonas agrícolas relativamente pobres o regiones apenas industrializadas hacia aquéllas ricas y altamente industrializadas y caracterizadas por marcadas diferencias en el idioma, la religión, y la cultura general - de lugar a un cambio en la situación de las mujeres hacia un plano menos "tradicional". 